\title{
Phosphorus distribution after three decades of different soil management and cover crops in subtropical region
}

\author{
Danilo Rheinheimer, Mayara Regina Fornari, Marilia Camotti Bastos, Gracieli Fernandes, \\ Maria Alice Santanna, Ademir Calegari, Lutécia Beatriz dos Santos Canalli, Laurent CANER, \\ Jerome Labanowski, Tales Tiecher
}

Keywords No-tillage; conventional tillage; P forms

Taxonomy Winter Cover Crops, Continuous Non-Tilled

Corresponding Author Tales Tiecher

Corresponding Author's Institution

: Universidade Federal do Rio Grande do Sul

\begin{abstract}
The no-tillage system with normally comprise winter cover crops and crop rotation may increase the efficiency use of soil $\mathrm{P}$ and phosphate fertilizer. The objective of this study was to evaluate the effect of three decades of different soil management systems and winter cover crops on the fractions of $\mathrm{P}$ in a clayey oxisol of Paraná State, Brazil. The bi-factorial experiment with three replicates was installed in 1986. The main plots consisted of seven treatments of winter cover plants and in the subplots, two tillage systems were used: no-tillage and conventional tillage. The soil was sampled in the $0-10 \mathrm{~cm}$ soil layer in the post-harvest periods of the corn (harvest 2014-2015), the flowering of the winter cover plants (2015) and soybean flowering (harvest 2015-2016). The different pools of P were evaluated. In a short time of no-tillage adoption (30 years) with phosphate fertilizers addition, the amount of $\mathrm{P}$ organic pools and type of $\mathrm{P}$ organic compound were likewise to the natural biome. The notillage guaranteed higher inorganic and organic $\mathrm{P}$, both rapid and moderately available, in comparison to the conventional tillage system. However, in the conventional tillage during (40 years -80 plows +160 harrows), despite the addition of $3 \mathrm{Mg} \mathrm{ha}^{-1}$ of $\mathrm{P}_{2} \mathrm{O}_{5}$, the available and moderately phosphorus in soil surface were very similar to soil under natural forest. In the natural biome, the amount of $\mathrm{P}$ stored in soil microbial biomass was stable in the time showing a homeostatic equilibrium. Nevertheless, in cultivated soil and fertilized with inorganic phosphate, there was a synchronism between plant demand and storage in soil microbial biomass.
\end{abstract}

Key words: No-tillage; conventional tillage; cover crop; P adsorption/desorption; microbial biomass; natural forest

\section{Introduction}

World population growth is increasing demand for food (Bijl et al., 2017), which highlights the importance of the current stimulation of more efficient agricultural production systems. For this purpose, the main strategies are the intensification of the existing agricultural land and the expansion of cultivated areas to the detriment of native 
vegetation. However, both strategies are detrimental to global biodiversity. Another option possible could be recovering soil of degraded pastureland. In Brazil, the new arable land available for cropland is restrict to the degraded pasture or natural biome, specially Cerado biome, which predominate very old and weathered soils. Thus, at the beginning of the exploitation of these new agricultural areas, the soils needs high $\mathrm{P}$ application rates in order to overcome their large $\mathrm{P}$ adsorption capacity. Beyond, the intensification of cultivated land suggests additional fertilizer application resulting in amounts of $\mathrm{P}$ twice times the plants' demands (Withers et al. 2018). In addition, natural reserves of phosphate fertilizers are limited and they are reducing all over the world (Elser et al., 2014). In this way, soil management in agricultural land needs to be improved by the better use of fertilizers. Soil management can alters the dynamics of $\mathrm{P}$ transformations in a beneficial way by better utilization of $\mathrm{P}$ in the soil or harmful way through losses of this nutrient and the exacerbated applications (Rheinheimer et al., 2008a). In the no-tillage system (NT) it is recommended to keep the straw on the soil surface, providing the accumulation of organic matter. The presence of straw results in the increase of microbial activity and in greater mineralization of nutrients such as P (Corbeels et al., 2016), making readily available nutrients for plant roots uptake.

Another way to change the dynamics of soil $\mathrm{P}$ is growing different plant species in a consortium (mixing) and/or singles (Soltangheisi et al., 2018). This is due to the different strategies of obtaining $\mathrm{P}$ by the distinct species and to the lability of $\mathrm{P}$ in the forms accumulated in their tissues (Tiecher et al., 2012a, 2012b; Horst et al., 2001). The main strategies used by plants to intercept and absorb $\mathrm{P}$ are: (i) the increase in the ratio between root and shoot, (ii) the increase of root bristle in quantity, shape or thickness to ensure greater exploration of soil volume, (iii) the root exudation of the acid phosphatase enzyme or low molecular weight organic compounds which, through binder exchange reactions or occupation of the adsorption site, promote the mobilization of $\mathrm{P}$ and also (iv) through association with other microorganisms (Chavarría et al., 2016; Zhang et al., 2014). In addition, cover crops may have a regulatory effect on the enzymatic activity related to mineralization of soil organic P (Po). For example, radish (Raphanus sativus Mill.), a crop with large root excretion of malic acid, can significantly increase the availability of $\mathrm{P}$ in the soil solution (Pavinato and Rosolem, 2008).

Therefore, the rotations of different cover crops with different strategies to access $\mathrm{P}$ from the soil, especially with well-developed root systems, can increase soil P availability, changing the P cycle mainly in the long-term (Soltangheisi et al., 2018, Damon et al., 2014). 
This effect can be optimized when the plant residue is maintained in the soil surface, such as in NT system (Rheinheimer et al., 2008a). Accordingly, to the soil management and plants physiological adaptations, the utilization efficiency of $\mathrm{P}$ added via fertilizer can be improved (Teles et al., 2017). The consequence of a more efficient use of $P$ that is already in the soil is the reduction of its wide application in agricultural land, resulting in a more sustainable agriculture. Another important factor in crop management and rotation is microbiological activity since the $\mathrm{P}$ cycle in the soil is mainly controlled by microbial activity (Yevdokimovet al. 2016). The microorganisms are responsible for the storage of $P$ through the immobilization inside their tissues, avoiding $\mathrm{P}$ adsorption in the inorganic colloids of the soil. By the senescence, death and cellular lysis of these organisms, P becomes part of the Po of the soil, being mineralized and available to the soil solution and then uptake by the plant roots (Bünemann, 2015; Darch et al., 2014; Martinazzo et al., 2007; Conte et al., 2002). Thus, changes in Po availability are also susceptible to soil management, especially in the longterm.

It is commonly known that continuous addition of cover crops residues in the long-term on the soil surface of no-tilled soils in succession to commercial crops markedly changes the magnitude of soil chemical and biological processes (Pavinato et al., 2017, Damon et al., 2014, Tiecher et al., 2012a 2012b; Wutke et al., 2014). However, long term studies about these changes are still scarce, especially in consolidated crop systems. Recently Haygartha et al. (2018) in their perceptive paper "On the history and future of soil organic phosphorus research: a critique across three generations" affirm that the "Soil organic phosphorus has broad agronomic and ecological significance, but remains a neglected topic of research".

The objective of this study was to compare the $\mathrm{P}$ distribution in subtropical soils cultivated three decades under different soil tillage systems and winter cover crops.

\section{Material and methods}

\subsection{Study site and experimental design}

The experimental area is located at the Experimental Station of Paraná Agronomic Institute - IAPAR (52 $41^{\prime} \mathrm{W}, 2^{\circ} 07^{\prime} \mathrm{S}, 700 \mathrm{~m}$ asl), in Paraná state, Brazil. The relief in the area is smooth wavy with slope ranging from 4 to $7 \%$. The soil of the region was formed from basaltic and is classified as very acid Oxisol (clayey Rhodic Hapludox) (70\% clay, 15\% silt and $15 \%$ sand). The soil mineralogy is composed of $130 \mathrm{~g} \mathrm{~kg}^{-1}$ of $2: 1$ clay minerals, $680 \mathrm{~g} \mathrm{~kg}^{-}$ 
${ }^{1}$ of $1: 1$ clay minerals (kaolinite and halloysite), $140 \mathrm{~g} \mathrm{~kg}^{-1}$ of iron oxides (51\% hematite, $36 \%$ goethite and $13 \%$ magnetite) and $50 \mathrm{~g} \mathrm{~kg}^{-1}$ of gibbsite (Costa, 1996). According to the classification of Köppen, the climate of the region is $\mathrm{Cfb}$ subtropical humid with average annual precipitation ranging from 1,200 to $1,500 \mathrm{~mm}$ and miminal and maximal mean annual temperature of 15.6 and $25.7{ }^{\circ} \mathrm{C}$. Variation of temperature and precipitation from October 2014 to March 2016 is presented in Figure 1.

In the summer of 1976, the native forest was cleared to grow corn (Zea mays L.) and beans (Phaseolus vulgaris L.). Both species were cultivated for 10 years under conventional tillage (CT) with plowing that resulted to intensive soil erosion, soil degradation and decrease of soil quality. In 1986, the experiment was set up with a randomized block design, in a factorial system of subdivided plots (bi-factorial), with three replications. The winter cover species were allocated to the main plots $(20 \times 12 \mathrm{~m})$ and the subplots $(20 \times 6 \mathrm{~m})$ with the soil preparation systems of CT and NT. The treatments of the main plots consisted of seven winter cover crops: ryegrass (Lolium multiflorum L.), rye (Secale cereal L.), common vetch (Vica sativa L.), consortium of hairy vetch (Vicia villosa Roth) and black oat (Avena strigosa Schreb), radish (Raphanus sativus Mill.), wheat (Triticum aestivum L.) and fallow. During the summer, the whole area was cultivated with soybean (Glycine max L.) or corn (Zea mays L.) (Table 1). Soil under CT continued to be prepared with one plowing and two disc-harrowing, before each cultivation.

All treatments received the same amounts of limestone, nitrogen $(\mathrm{N})$, phosphorous $(\mathrm{P})$ and potassium (K), according to the recommendation of IAPAR (2003). The nutrients P and $\mathrm{K}$ and one third of $\mathrm{N}$ were applied in the line during the sowing, and the remaining $\mathrm{N}$ was applied 45 days after sowing. A total of 2,020 kg ha-1 of $\mathrm{P}_{2} \mathrm{O}_{5}, 995 \mathrm{~kg} \mathrm{ha}^{-1}$ of $\mathrm{K}_{2} \mathrm{O}$ and $668 \mathrm{~kg}$ $\mathrm{ha}^{-1}$ of $\mathrm{N}$ were applied from 1986 to 2016. In addition, between 1976 and 1986, approximately $1,000 \mathrm{~kg} \mathrm{ha}^{-1}$ of $\mathrm{P}_{2} \mathrm{O}_{5}$ was added in the experimental area. The last two lime applications were performed in 2011 and 2015, using a rate of $2 \mathrm{Mg} \mathrm{ha}^{-1}$ (Table 1). The herbicides were used to control weeds in the fallow and, in some cases, to complement the thinning of the aerial part of the winter cover crops. Wheat was harvested for grain until 1995 ( 7 crops) and after that was managed as a cover crop (Table 1 ).

During the 30 years of the experiment, the dry matter of the aerial part of the cultivated plants was evaluated during the winter and summer (Table 2). In the fallow treatment, without annual crop cultivation in the winter period, the biomass yield represents weeds and summer crops. 


\subsection{Soil sampling and physical-chemical characterization}

The soil was sampled in three periods: (i) after the corn crop cycle (March 2015); (ii) in the flowering of the winter species (September 2015); (iii) in the flowering of soybean (February 2016). Soil sampling was performed in triplicate in the 0-10 cm soil layer using a cutting blade. In addition, "reference" soil samples were taken in an adjacent area with native forest. After sampling, the soil was packed in polystyrene boxes, stored at $4^{\circ} \mathrm{C}$, and transferred to the laboratory, where it was sieved with a $185 \mu \mathrm{m}$ mesh for analysis.

The total $\mathrm{N}$ content was obtained through digestion, according to the methodology proposed by Tedesco et al. (1995). Total organic carbon (TOC) was determined by the Mebius method in the block (Rheinheimer et al., 2008b). The exchangeable K was extracted by Mehlich-1 $\left(0.05 \mathrm{~N} \mathrm{HCl}\right.$ and $\left.0.025 \mathrm{~N} \mathrm{H}_{2} \mathrm{SO}_{4}\right)$ solution and determined by atomic emission spectrometry. The exchangeable calcium $\left(\mathrm{Ca}^{2+}\right)$, magnesium $\left(\mathrm{Mg}^{2+}\right)$ and aluminum $\left(\mathrm{Al}^{3+}\right)$ cations were extracted with $1 \mathrm{~mol} \mathrm{~L}^{-1} \mathrm{KCl}$. Aluminum was determined by titration with $\mathrm{NaOH}$ $0.0125 \mathrm{~mol} \mathrm{~L}^{-1}$ and $\mathrm{Ca}$ and $\mathrm{Mg}$ by atomic absorption spectrometry (Tedesco et al., 1995).

The $\mathrm{pH}$ value was determined in water (soil:solution ratio 1:1) and the potential acidity $(\mathrm{H}+\mathrm{Al})$ was estimated using the TSM method $(37.5 \mathrm{mM}$ triethanolamine; $17.3 \mathrm{mM}$ de imidazole; $30.7 \mathrm{mM}$ 2-( $N$-morpholino) ethanesulfonic acid; $20.7 \mathrm{mM}$ calcium acetate and $721 \mathrm{mM}$ calcium chloride, wiht adjusted pH at 7.5) (Santa Maria Buffer - Toledo et al., 2012). The sum of bases (S) was determined by the sum of the $\mathrm{K}^{+}+\mathrm{Ca}^{2+}+\mathrm{Mg}^{2+}$ cations. The effective CEC ( $\left.\mathrm{CEC}_{\text {effective }}\right)$ was calculated by the sum of $\mathrm{S}$ plus the concentration of $\mathrm{Al}^{3+}$. The cation exchange capacity at $\mathrm{pH} 7.0\left(\mathrm{CEC}_{\mathrm{pH} 7}\right)$ was calculated by the sum of $\left(\mathrm{H}^{+}+\mathrm{Al}^{3+}\right)+\mathrm{Ca}^{2+}$ $+\mathrm{Mg}^{2+}+\mathrm{K}^{+}$. The base saturation $(\mathrm{V})$ was calculated using the equation: $\mathrm{V}(\%)=((\mathrm{S} /$ $\left.\left.\mathrm{CEC}_{\mathrm{pH} 7}\right) \times 100\right)$. The aluminum saturation $(\mathrm{m})$ was calculated by the equation: $\mathrm{m}(\%)=\left(\left(\mathrm{Al}^{3+}\right.\right.$ / $\left.\left.\mathrm{CEC}_{\text {effective }}\right) \times 100\right)$. The specific surface area (SSA) of the soil was determined by the BET isotherm technique using Quantachrome equipment, model NOVA 3200E. All these parameters are presented in Table 3.

\subsection{Phosphorous distribution}

\subsubsection{P stored in soil microbial biomass}

The $\mathrm{P}$ stored in soil microbial biomass $\left(\mathrm{P}_{\mathrm{SMB}}\right)$ was estimated by the fumigationextraction method (Hedley et al., 1982; Brookes and Powlson, 1982; Morel et al., 1996). For 
this purpose, $0.500 \mathrm{~g}$ of soil were weighed in four sets of tubes: the first set (PA) received the fumigation treatment on a saturated surface of chloroform in a vacuum oven for 24 hours (25 $\left.{ }^{\circ} \mathrm{C}\right)$; the second (PB) did not receive any treatment; the third set (PC) received a solution with $50 \mathrm{mg} \mathrm{L}^{-1}$ of $\mathrm{P}$, together with the extractor to determine the adsorption capacity of $\mathrm{P}$ by the soil; the latter set was used to determine the soil moisture. The extraction of $\mathrm{P}$ from the three sets was done with $0.5 \mathrm{~mol} \mathrm{~L}^{-1} \mathrm{NaHCO}_{3}$ at $\mathrm{pH}$ 8.5. After extraction, the samples were centrifuged at $2500 \times \mathrm{g}$ for 15 minutes and filtered through (pore size) filters to remove particulate matter. An aliquot of $3,0 \mathrm{~mL}$ of the filtered extract was taken and $5 \mathrm{~mL}$ of $7 \%$ solution of $\left(\left(\mathrm{NH}_{4}\right)_{2} \mathrm{~S}_{2} \mathrm{O}_{8}\right)(\mathrm{w} / \mathrm{v})$ and $0.5 \mathrm{~mL}$ of $1: 1(\mathrm{v} / \mathrm{v}) \mathrm{H}_{2} \mathrm{SO}_{4}$ solution were added. Afterward, the samples were submitted to digestion in an autoclave for 2 hours, at $1 \mathrm{~atm}$ and $121^{\circ} \mathrm{C}$, according to USEPA (1971). The determination of the P concentration present in each soil sample set was performed according to Murphy and Riley (1962). The content of P stored in the SMB expressed in relation to the dry soil was estimated by:

$$
P \text { stored in the } S M B=\frac{50 \times(P A-P B)}{0.40 \times(P C-P B)}
$$

\subsubsection{Available $P$}

For the other analyzes of $\mathrm{P}$ fractions, the soil collected was oven dried at $55{ }^{\circ} \mathrm{C}$, ground with a roller and sieved with a $2 \mathrm{~mm}$ mesh. The available $\mathrm{P}$ was extracted by the method of Mehlich-1 (Mehlich, 1953) and by the anion exchange resin - AER (plates AR 103 QDP 434, Rheinheimer et al., 2003). The P present in the extracts was determined according to Murphy and Riley (1962).

\subsubsection{Moderately available $P$}

Moderately available $\mathrm{P}$ was estimated by using a $0.5 \mathrm{~mol} \mathrm{~L}^{-1} \mathrm{NaOH}$ extraction by adding $10 \mathrm{~mL}$ to $0.5 \mathrm{~g}$ of soil followed by agitation for for 16 hours in an over and over agitator at $33 \mathrm{rpm}$, with subsequent centrifugation at $3000 \times \mathrm{g}$ for 15 minutes. Inorganic $\mathrm{P}$ $\left(\mathrm{Pi}_{\mathrm{NaOH}}\right)$ was determined by the Dick and Tabatabai (1977) method. The total P extracted by $\mathrm{NaOH}\left(\mathrm{PT}_{\mathrm{NaOH}}\right)$ was estimated after digestion of $3 \mathrm{~mL}$ of extract in an autoclave following the procedure presented in section 2.3 using the USEPA method (1971) and quantifying P by Murphy and Riley (1962) method. Subsequently, $\mathrm{Po}_{\mathrm{NaOH}}$ was obtained by the difference 
between $\mathrm{PT}_{\mathrm{NaOH}}$ and $\mathrm{Pi}_{\mathrm{NaOH}}$. The organic fraction $\left(\mathrm{Po}_{\mathrm{NaOH}}\right)$ is represented by monoester phosphates, predominantly (Rheinheimer et al., 2002).

\subsubsection{Total organic and inorganic $P$}

The $\mathrm{Po}_{\text {total }}$ content in the soil was estimated by calculating the difference between the $\mathrm{P}$ extracted from a sample ignited at $550^{\circ} \mathrm{C}$ for two hours inside muffle furnace and the nonignited sample. For both treatments, $0.25 \mathrm{~mol} \mathrm{~L}^{-1} \mathrm{H}_{2} \mathrm{SO}_{4}$ was used (Olsen and Sommers, 1982). $\mathrm{P}_{\text {total }}$ was quantified using $0.05 \mathrm{~g}$ of soil mineralized with concentrated sulfuric acid $\left(\mathrm{H}_{2} \mathrm{SO}_{4 \text { (conc.) }}\right)$ and a solution of saturated $\mathrm{MgCl}_{2 \text { (sat.) }}$ and $(1: 7.5-\mathrm{v} / \mathrm{v})$ at $200{ }^{\circ} \mathrm{C}$ for 1.5 hour. After cooling, $3 \mathrm{ml}$ of $\mathrm{H}_{2} \mathrm{O}_{2}$ was added and again heated at $100{ }^{\circ} \mathrm{C}$ for 1 hour. $\mathrm{P}$ was quantified by Murphy and Riley (1962) method. Pi $i_{\text {total }}$ was determined by the difference between $\mathrm{P}_{\text {total }}$ and $\mathrm{Po}_{\text {total }}$.

\section{4. ${ }^{31} P-N M R$ analysis}

Liquid-sate ${ }^{31} \mathrm{P}-\mathrm{NMR}$ was used to identify the main form of P...... The analyses were performed for two replicates of natural forest and common vetch winter cover crops (notillage and conventional tillage). The phosphorus was extracted with $50 \mathrm{~mL}$ centrifuge tubes with $40 \mathrm{~mL}$ of $0.25 \mathrm{~mol} \mathrm{~L}^{-1} \mathrm{NaOH}+50 \mathrm{mmol} \mathrm{L}^{-1}$ EDTA (Turner et al., 2005). We used duplicate extraction of $4 \mathrm{~g}$ of dried soil samples. The tubes were agitated for $4 \mathrm{~h}$ on an endover-end shaker at $20^{\circ} \mathrm{C}$ and centrifuged at $3,000 \times \mathrm{g}$ for 15 minute. The extract of one subsample was used to estimate total and organic $\mathrm{P}, \mathrm{Ca}, \mathrm{Mg}, \mathrm{Fe}$, and $\mathrm{Al}$ concentration and the second was frozen and lyophilized. Subsequently, the lyophilized extract was dissolved into $2.7 \mathrm{~mL}$ of $0.25 \mathrm{~mol} \mathrm{~L}^{-1} \mathrm{NaOH}+50 \mathrm{mmol} \mathrm{L}^{-1}$ EDTA and $0.3 \mathrm{~mL} \mathrm{D}_{2} \mathrm{O}$ was added and the mixture vortex-stirred for $5 \mathrm{~min}$. After 120 minutes of contact, the supernatant was separated by centrifugation $(3,000 \times g$ for $15 \mathrm{~min})$, filtered $(<0.45 \mu \mathrm{m})$ and transferred to $10 \mathrm{~mm} \mathrm{NMR}$ tubes. The P spectra were obtained in a Bruker Advance DPX 400 spectrometer at a frequency of $162 \mathrm{MHz}$ with proton decoupling. A pulse angle of $90^{\circ}$ was used at $20^{\circ} \mathrm{C}$ an acquisition time of 0.5 and 3 s relaxation time. The number of scans was of 23,568 to 31,600. The peak area was determined by electronic integration at a baseline of $1 \mathrm{~Hz}$.

The MestRe-C v 2.3a software was used for peak area integration. The chemical shifts of $7.49 \mathrm{ppm}$ for orthophosphate, 6.33 to $5.31 \mathrm{ppm}$ for monoester, -0.81 to $-0.69 \mathrm{ppm}$ for diester, -2.55 to $3.59 \mathrm{ppm}$ for pyrophosphate, and $9.35 \mathrm{ppm}$ for adenosine diphosphate 
(Turner et al., 2003; Cade-Menun, 2015). Total inorganic P was obtained from the sum of $\mathrm{NaOH}$ EDTA extractable inorganic orthophosphate and pyrophosphate, while total organic $\mathrm{P}$ was the sum of $\mathrm{NaOH}$ EDTA extractable orthophosphate monoesters, diesters and adenosine diphosphate.

\subsection{Statistical analysis}

The statistical model adopted was a tri-factorial, where the winter crops were the main plots, the soil tillage systems the subplots, and the sample time, the sub-subplots. Statistical analysis was carried out using ANOVA. Mean of treatments were tested for level of significance at $5 \%$ probability of error. When the effects of the treatments were significant, the differences between winter crop media, soil preparation systems, and soil collection times were compared by the Tukey test (Table 4). The values for microbial P and Mehlich P did not follow a normal distribution and were presented in scale.

\section{Results and discussion}

\subsection{Consequence of the conversion of a natural forest to an agroecosystem}

The content of $\mathrm{P}$ stored is soil microbial biomass (Table 5) in the natural forest was approximately eight times higher than the amount of available $\mathrm{P}$ extracted by Mehlich 1 or resin extractors (Table 6). This is a normal behavior in the subtropical natural biome (Martinazzo et al., 2007). Although $\mathrm{P}_{\mathrm{SMB}}$ is considered one of the soil insoluble $\mathrm{P}$ forms, it can be considered as a source of P potentially available for plant nutrition (Blackwell et al., 2010; Darch et al., 2014). After thirty years of NT system, the $\mathrm{P}_{\mathrm{SMB}}$ content (mean $=47.9 \mathrm{mg}$ $\mathrm{kg}^{-1}$ ) was higher than in the natural forest (mean $=40.3 \mathrm{mg} \mathrm{kg}{ }^{-1}$ ). The absence of soil disturbance and sufficient $\mathrm{P}$ input rate promote high crop grain yield, adequate environment for soil microbiota development and slow and constant organic matter increase. Biotic processes such as microbial immobilization, remineralization of immobilized $\mathrm{P}$ and nonmicrobial Po mineralization by soil microorganisms have great relevance for $\mathrm{P}$ cycling in soil (Bünemann, 2015). In contrast, in CT system, with the same rate of P inorganic fertilization, the $\mathrm{P}_{\mathrm{SMB}}$ content was only $24.7 \mathrm{mg} \mathrm{kg}^{-1}$ (mean). This represent only $52 \%$ and $61 \%$ of the amount of $\mathrm{P}_{\mathrm{SMB}}$ accumulated in soil under NT and under natural forest, respectively. 
The study of $\mathrm{P}$ distribution highlights that three decades of agricultural practice can significantly modify its distribution. Thus, under natural forest, $33.6 \%$ of $\mathrm{P}_{\text {total }}$ is in organic form (436 mg kg${ }^{-1}$ ) and under cultivated soil the organic P account for $30.2 \%$ (371 $\mathrm{mg} \mathrm{kg}^{-1}$ ) and $30.3 \%$ (463 $\mathrm{mg} \mathrm{kg}^{-1}$ ) of total P in CT and NT, respectively (Table 6). The same tendency was observed for the moderately labile organic P $\left(389,364\right.$ and $277 \mathrm{mg} \mathrm{kg}^{-1}$, for natural forest, NT and CT, respectively). The soil mobilization by plow may decrease slowly the soil organic carbon and, consequently, promote the mineralization of organic P. After soil degradation, it is more difficult to recover the original amount of soil organic carbon observed in the natural biome. In this case, a very clayed soil, ten years of inadequate soil use and management (deforestation followed by CT system from 1976 to 1986) need 30 years (1986 2016) of adequate and high productions system for recovery the similar soil quality. The intensive soil mobilization reduced the soil organic carbon and nitrogen stocked in soil biomass microbial, the polysaccharide content and phosphatase activity, in relation to NT system (Balota et al., 2014).

Only $4.6 \mathrm{mg} \mathrm{kg}^{-1}$ of the $1,298 \mathrm{mg} \mathrm{kg}^{-1}$ of total $\mathrm{P}$ was available in natural forest due to the adsorption on the minerals with $680 \mathrm{mg} \mathrm{kg}^{-1}$ of $1: 1$ clay mineral and $190 \mathrm{mg} \mathrm{kg}^{-1}$ of iron and aluminum oxides. These results highlight that soil $\mathrm{P}$ solubility is essentially controlled by sorption/desorption and mineralization/immobilization process. The organic carbon accumulated in soil surface (3.6\%) (Table 2) and constant low-molecular organic acids (Hou et al., 2018) production by microbial activity can be uphold bioavailable pool of "biological P" (biomass microbial and plant residues) and the plant demand is more biological than chemical dependent. Secondary and not negligible are the root and microbial phosphatase enzymes production and mycorrhizal symbiosis (Wang et al., 2017) and trees high Presorption efficiency (Tsujii et al., 2017). After Walker and Syers (1976) study, it is admitted that in soils with very advanced stage of weathering, soil organic carbon cycling generally control the biological availability of P. Recently, Huang et al. (2017) showed that all soil chronosequence under natural aerobic conditions, soil organic $\mathrm{P}$ was dominated by phosphate monoesters (inositol phosphates), followed by phosphate diesters and phosphonates. However, the monoesters are very strongly adsorbed and their bioavailability is very limited (Turner et al., 2005).

The liquid-sate ${ }^{31} \mathrm{P}-\mathrm{NMR}$ analyses sowed four $\mathrm{P}$ compound groups in natural forest and no-tillage system (orthophosphate, monoester, diester and adenosine diphosphate). In the CT, adenosine diphosphate was not detectable (Table 7). The rations monester/diester were 5.9, 8.5 and 7.4 for forest, NT and CT, respectively. The organic P compounds groups were 
responsible to $46.4 \%, 33.7 \%$ and $40.9 \%$ of total P present in NMR extract for forest, NT and CT, respectively. Despite the higher absolute value, the lower percentage of organic P in NT in relation of CT is due higher available and moderately available inorganic P (Table 6 and 7) from inorganic fertilizer added in soil surface and no soil mobilization. The adequate soil management and $\mathrm{P}$ addition in subtropical conditions guarantee high plant production, high microbial activity and diversity of organic $\mathrm{P}$ similar to the natural forest.

However, the representatively of total organic $\mathrm{P}$ in liquid-sate ${ }^{31} \mathrm{P}-\mathrm{NMR}$ extract is doubtful. Only --.-\% of total P was extracted by $\mathrm{NaOH}$-EDTA. This value is much closed to observed for tropical soils (37\% - Turner, 2008) and forest soil (34\% - Cade-Menun et al., 2002). In the natural forest soil approximately --.-\% of total organic $P$ was extracted; in contrast more than --.-\% in cultivated soils. Therefore, the NaOH-EDTA extractor has a selective capacity of organic $\mathrm{P}$ extraction and can compromised the liquid-sate ${ }^{31} \mathrm{P}-\mathrm{NMR}$ results. Aleixo (2018) showed that organic P extracted by NaOH-EDTA was less than $10 \%$ of total $\mathrm{P}$ in tropical soil in natural forest and cocoa agroforests production. The amount of total $\mathrm{P}$ extracted depend of anthropic $\mathrm{P}$ addition, and is recovery in inorganic pools (18, 23 and $44 \%$ for natural forest, cacao without $\mathrm{P}$ fertilizer and cacao with $\mathrm{P}$ fertilizer, respectively). Doolette et al. (2011) observed similarly results in Australian soils.

\subsection{Effect of a soil tillage practice}

After 30 years of adequate soil management adoption for subtropical conditions (NT, cover crops and regular fertilization) the $\mathrm{P}$ stored in soil microbial biomass was twice as the CT (Table 5). In the NT system, $240.7 \mathrm{Mg} \mathrm{ha}^{-1}$ of shoot plant residues was deposited in soil surface during the last three decades. Considering that root/shoot biomass is of $46 \%$ for corn and $55 \%$ for cover crop (Austin et al., 2017), the biomass input was nearly twice. The minimum soil disturbance promoted more stable and diverse microbial activity and high $\mathrm{C}, \mathrm{N}$, $\mathrm{S}$ and $\mathrm{P}$ turnover in relation to the CT system. The high organic carbon (Table 2) in soil surface make possible the incorporation of $\mathrm{P}$ in organic pools, especially in moderately bioavailable form extracted by $\mathrm{NaOH}$ (Rheinheimer and Anghinoni, 2006) and in $\mathrm{P}_{\mathrm{SMB}}$ (Conte et al., 2002; Rheinheimer et al., 2008a; Damon et al., 2014; Mackay et al., 2017). The $\mathrm{P}$ immobilization by the SMB delays the specific adsorption with high binding energy of $\mathrm{P}$ by the soil clay minerals (Martinazzo et al., 2007; Rodrigues et al., 2016; Zamuner et al., 2008). Then, after lysis of the microbial cells and $\mathrm{P}$ mineralization, the $\mathrm{P}$ inorganic is released into the soil solution and can be uptake by plants and microorganisms. 
The amount of moderately bioavailable organic P in NT was $31.4 \%$ higher than in the CT (364 and $277 \mathrm{mg} \mathrm{kg}^{-1}$, respectively - Table 5). This organic P pool is constituted mainly by orthophosphate monoester (Figure 2). They are strongly adsorbed by ligand exchange at surface functional groups of iron and aluminum oxides and kaolinite (Turner et al., 2005) forming inner sphere complexes, which hinders its mineralization by microorganisms (Pavinato and Rosolem, 2008) and then accumulate in soils in the long-term (Jian et al., 2017). These authors showed that steady state for $P$ organic monoesters were 113 and 91 years in paddy and no-paddy soils in China, respectively. In our case, we can consider that the steady state for moderately bioavailable organic phosphorus $\left(389 \mathrm{mg} \mathrm{kg}^{-1}\right)$ in natural forest occur in the long-term because the natural forest was established around 20 thousand years ago. In a short-time of NT adoption with phosphate fertilizers addition (only 30 years), the amount of this $\mathrm{P}$ organic pools is likewise to the natural biome.

The Pi moderately bioavailable was also higher in NT than CT (211 and $127 \mathrm{mg} \mathrm{kg}^{-1}$, respectively). In NT system, the inorganic P added by fertilizers was partially adsorbed with moderate energy contrasting with intensive soil mobilization (CT). In this case, CT, the Pi moderately bioavailable was lower than accumulated in the natural forest. The soil plowing exposes the $\mathrm{P}$ in the soil solution to new active adsorption sites present in the inorganic colloid surface, especially in hydroxyl groups coordinated by one Fe atoms or in the Al-OH functional groups at the edges of kaolinite. In the goethite surface, the P can be formed binuclear inner sphere complexes in monocoordinated hydroxyl groups (Barrón and Torrent, 1996; Parfitt, 1989). However, in NT system the dissolution of fertilizer is restricted to a small volume of soil around fertilizer granule and the functional groups are quickly saturated and the binding energy of $\mathrm{P}$ with the soil decrease (Parfitt et al., 1975). The new phosphate added will then be less adsorbed because the soil is already saturated (Barrow, 1998). Additionally, the higher organic carbon content recovers the surface of clay minerals and oxides (Kleber and Johnson, 2010) decreasing their reactivity.

In more sustainable soil management for tropical and subtropical conditions regions, like no-tillage system, the protection of soil surface by plant residues decreases the fluctuation of water content and the average soil temperature (Blanco-Canqui and Ruis, 2018). The biologic activity is more stable in the time and the rate of organic carbon mineralization is lower than in conventional tillage system (Calegari et al., 2008). Similarly, to a natural biome, there are constant and dynamic low-molecular organic acids production that can compete with active sites of the soil inorganic colloids, reducing the adsorption of $\mathrm{P}$ on their surface (Fink et al., 2016). 
The available inorganic $\mathrm{P}\left(\mathrm{P}_{\mathrm{M}}\right.$ and $\left.\mathrm{P}_{\mathrm{R}}\right)$ contents were higher in the soil under NT in relation to the $\mathrm{CT}$ soil (Table 6). The value of available $\mathrm{P}$ in $\mathrm{CT}$ is lower than the critical level for grain production (9 $\left.\mathrm{mg} \mathrm{kg}^{-1}-\mathrm{SBCS} / \mathrm{NEPAR}, 2017\right)$. Even after the addition of almost 3 $\mathrm{Mg} \mathrm{ha}^{-1}$ of $\mathrm{P}_{2} \mathrm{O}_{5}$ in the last 40 years of cultivation (80 plows +160 harrows), the available $\mathrm{P}$ in soil surface $(0-10 \mathrm{~cm})$ of CT was very similar to the soil under natural forest (Table 6). The P added via inorganic fertilizer is redistributed and diluted in the plowed layer $(0-20 \mathrm{~cm}$ Tiecher et al., 2017; 2012a) and it is adsorbed in inorganic colloid surface by inner-sphere complex. The predominance of inorganic forms and unavailable pools are related to high concentrations of hematite, goethite and 1:1 clay-minerals in the soil (Table 2).

Using the same $\mathrm{P}$ fertilizer rates, the soybean and corn production with $\mathrm{CT}$ is $6 \%$ and $11 \%$ lower than in NT system (Calegari et al., 2008; 2012). So, the different soil management systems affect the dynamics of $\mathrm{P}$ pools and their bioavailability to crops. Changes in $\mathrm{P}$ pools after 30 years of fieldwork indicate that the results can be interpreted as "laws" (general trend) rather than just as punctual results. These changes may not be detected in the short-term as they affect the redistribution of $\mathrm{P}$ in the soil gradually.

\subsection{Effect of winter cover crops on soil phosphorus forms}

Soils continuously under fallow with spontaneous vegetation in the winter presented the lowest levels of $\mathrm{P}$ stored in soil microbial biomass (mean $=28 \mathrm{mg} \mathrm{kg}^{-1}$ ) for the three sampling time compared to soils with cultivated species (mean $=39 \mathrm{mg} \mathrm{kg}^{-1}$ ), except for wheat (Table 5). Total aboveground biomass yield during 30 years in fallow was 58.0 and $44.7 \mathrm{Mg} \mathrm{ha}^{-1}$ in NT and CT system, respectively. When winter cover crops were cultivated the values were increased up to 119.5 and $86.1 \mathrm{Mg} \mathrm{ha}^{-1}$, in NT and CT system, respectively. Furthermore, the lower soil surface covering in fallow treatment expose the soil to erosion and fluctuation of soil water content and temperature, as well as lower effects of winter crops (shoot and roots), contributed to decreases the microorganism activity.

For the others $\mathrm{P}$ pools, regardless its nature (organic or inorganic) or degree of bioavailability, the winter cover crops effect was despicable or absent, compared to winter fallow effects (Table 6). The pools of organic and inorganic moderately available $\mathrm{P}$, and, organic total $\mathrm{P}$ in soil cultivated with radish were lower than others winter cover plants. Radish is a non-mycorrhizal plant, with higher activity of the acid and alkaline phosphatase enzymes in the soil, promoting a greater mineralization of organic P (Dalla Costa and Lovato, 2004). Due to its main and aggressive central root system and/or due to the high 
decomposition rate of its dry biomass (Loss et al., 2015), radish may have contributed to the distribution and recycling of $\mathrm{P}$ in depth and decreasing its concentration in the less labile pool in the superficial layer. The soil cultivated with ryegrass has less total inorganic $\mathrm{P}$ and total $\mathrm{P}$ in relation to others winter plants.

It should be noted that only 19 of the 30 winter's seasons were grown with the different winter cover crops. In the other eleven years, all treatment, except fallow, was cultivated with the same species, especially, black oat (Table 1). Moreover, in spring/summer all treatments were cultivated with the same culture (corn or soybean). Approximately 54 and $57 \%$ of total residues was originating from maize + soybean (Table 2 ). The plant type effect in soil $\mathrm{P}$ dynamic is small or unclear comparatively to soil management system. Much contradiction about the effects of cover crops on microbial community and activity in bulk soil and rhizosphere is reported in the literature (Ridder-Duine et al., 2005). Marschner et al. (2001) supported that bacterial community arrangement is the result of a complex plant and soil interaction.

\subsection{Effect of soil sampling time on soil phosphorus forms}

In the natural biome, the P stored by SMB oscillated to 38 from $45 \mathrm{mg} \mathrm{kg}^{-1}$ between the sampling times (Table 5). The "mature" subtropical natural forest is a system in homeostatic equilibrium. The $\mathrm{P}$ in plant biomass, litter and soil microbial biomass are connected by microbial activity (Solomon et al., 2002), but the stock of $\mathrm{P}_{\mathrm{SMB}}$ is very stable over time. In contrast, in perturbed natural biome, the fluctuation of $\mathrm{P}_{\mathrm{SMB}}$ content is very large and liked to root / shoot alteration (Rheinheimer et al., 2008a). In very clayey, highly weathered acidic soils, which severe $\mathrm{P}$ scarcity, the plant-microorganism interaction and trees high $\mathrm{P}$ resorption efficiency are very developed. Richardson and Simpson (2011) stated that extension or stimulation of root growth and/or direct physiological and metabolic were the mechanism of microbial-mediated plant growth promotion. The nutrients stored in SMB are an intermediate pool between litter decomposition and plant absorption. The mineralization and immobilization process of $\mathrm{P}$ due to microbial activity occurs rapidly and close to the roots (rhizosphere), allowing only a small fraction of $\mathrm{P}$ to be adsorbed by $\mathrm{Fe}$ and $\mathrm{Al}$ oxides (Vincent et al., 2010).

In the agroecosystem, the sampling time has high impact in the $\mathrm{P}$ stored in soil microbial biomass, but lower effect in the other P pools (Table 5 and 6). This pool is a highly dynamic and significant changes occur in response to the environment, especially when 
inorganic soluble P fertilizers are applied. During flowering stage of winter cover plants and soybean, the $\mathrm{P}_{\mathrm{SMB}}$ was lower than detected in soil after corn harvest (Table 5). Thus, in cultivated soil and fertilized with inorganic phosphate, there is a synchronism between plant demand and soil microbial biomass storing (Martinazzo et al., 2007). When the P plant demand is high, the root system and its association (mycorrhiza, e.g.) increase the $\mathrm{P}$ absorption from soil solution. The $\mathrm{P}$ depletion in rhizosphere amendment many chemical and biological process to guarantee the plants requirement. Consequently, there is an increased acid phosphatase activity (Allison et al, 2007; Dalla Costa and Lovato, 2004), promoting the hydrolysis of organic phosphates, especially the diester (Klose and Tabatabai, 1999), and the $\mathrm{P}_{\mathrm{SMB}}$ is partially mineralized.

After the reproductive stage is reached, plants go into the senescence and death. They drastically reduce $\mathrm{P}$ absorption until it completely ceases. Concomitantly, there is release of large amount of exudates in the rhizosphere. Finally, the whole the corn straw fragmentation that is deposited on soil surface, stimulate microbiological activity and thus immobilize large amounts of P into microbial biomass (Table 5). Both biological and geochemical processes of phosphate immobilization / adsorption were rapid (Olander and Vitousek, 2004). Therefore, the immobilized P in SMB is a labile pool that is protected from reactions with inorganic soil colloid, but temporarily unavailable to plants. When the winter cover crops, cultivated in succession to corn, have a demand for $\mathrm{P}$, the rate of release of microbial biomass will be higher and the turnover time is very short. These results are in agreement with Olander and Vitousek (2004), who concluded that in a tropical forest "microbes may play an important role in controlling $\mathrm{P}$ partitioning into biological versus geochemical sinks even in soils that have high sorption capacity".

\section{Conclusion}

The use of no-tillage system and adequate rate of phosphorus inorganic fertilizer for 30 years allowed the increase phosphorus stored in soil microbial biomass, recovering the amount stored in natural forest. In a short time of no-tillage adoption with phosphate fertilizers addition, the amount of phosphorus organic pools is likewise to the natural biome. The no-tillage guaranteed higher inorganic and organic phosphorus, both rapid and moderately availability, in comparison to conventional system. The phosphorus not exported by the grain harvested, it was accumulated in the moderately labile and non-labile polls. However, in the conventional tillage during 40 years with 80 plows +160 harrows, despite 
the addition of $3 \mathrm{Mg} \mathrm{ha}^{-1}$ of $\mathrm{P}_{2} \mathrm{O}_{5}$, the available and moderately phosphorus in soil surface was very similar to soil under natural forest.

In the natural biome, the amount of phosphorus stored in soil microbial biomass was stable in the time showing a homeostatic equilibrium. Nevertheless, in cultivated soil and fertilized with inorganic phosphate, there was a synchronism between plant demand and stocking in soil microbial biomass.

Soils continuously with spontaneous vegetation in the winter (fallow) presented the lowest levels of phosphorus stored in soil microbial biomass compared to soils cultivated with winter cover crops, except for wheat. For the others phosphorus pools, regardless its nature (organic or inorganic) or degree of bioavailability, the winter cover plants effect was despicable or absent, compared of winter fallow.

\section{Acknowledgments}

Coordination for the Improvement of Higher Education Personnel (CAPES). Brazilian National Council for Scientific and Technological Development (CNPq). Agricultural Research of Paraná (IAPAR). Laboratory of Nuclear Magnetic Resonance of Federal University of Santa Maria.

\section{References}

Aleixo, S., 2018. Especiação e transformações do fósforo orgânico em solos florestais e agroflorestais na região da mata atlântica no Brasil. Campos dos Goytacazes, RJ. Tese (Doutorado em Produção Vegetal) - Universidade Estadual do Norte Fluminense Darcy Ribeiro, Centro de Ciências e Tecnologias Agropecuárias. 93p.

Allison, V.J., Condron, L.M., Peltzer, D.A., Richardson, S.J., Turner, B.L., 2007. Changes in enzyme activities and soil microbial community composition along carbon and nutrient gradients at the Franz Josef Chrono sequence, New Zealand. Soil Biol. Biochem. 39, 17701781 .

Austin, E.E., Wickings, K., McDaniel, M.D., Robertson, G.P., Grandy, A.S., 2017. Cover crop root contributions to soil carbon in a no-till corn bioenergy cropping system. GCB Bioenergy. 9(7), 1252-1263.

Balota, E.L., Calegari, A., Nakatani, A.S., Coyne, M.S., 2014. Benefits of winter cover crops and no-tillage for microbial parameters in a Brazilian Oxisol: A long-term study. Agriculture, Ecosystems and Environment. 197, 31-40. 
Barrón, V., Torrent, J., 1996. Surface hydroxyl configuration of various crystal faces of hematite and goethite. Journal of Colloid and Interface Science. 177(2), 407-410.

Barrow, N.J. The four laws of soil chemistry: the Leeper lecture 1998. 1999. Aust. J. Soil Res., 37:787-829.

Bijl, D.L., Bogaart, P.W., Dekker, S.C, Stehfest, E., Vries, B.J.M., Vuuren, D.P., 2017. A physically-based model of long-term food demand. Global Environ Change. 45, 47-62.

Blackwell, M.S.A., Brookes, P.C., Fuente-Martinez, N., Gordon, H., Murray, P.J. Snars, K.E., Williams, J.K., Bol, R., Haygarth, P.M., 2010. Phosphorus solubilization and potential transfer to surface waters from the soil microbial biomass following drying-rewetting and freezing- thawing. Adv. Agron. 106, 1-35.

Blanco-Canqui, H, Ruis, S.J., 2018. No-tillage and soil physical environment. Geoderma. 326, 164-200.

Brookes, P.C, Powlson, D.C., 1982. Preventing phosphorus losses during perchloric acid digestion of sodium bicarbonate soil extracts. J. Sci. Food Agric. 32, 671-674.

Bünemann, E.K., 2015. Assessment of gross and net mineralization rates of soil organic phosphorus - a review. Soil Biol Biochem. 89, 82-98.

Cade-Menun, B.J., 2015. Improved peak identification in 31P-NMR spectra of environmental samples with a standardized method and peak library. Geoderma. 257-258, 101-114. , http://dx.doi.org/10.1016/j.geoderma.2014.12.016.

Cade-Menun, B.J., Liu, C.W.Nunlist, R., McColl, J.G., 2002. Soil and Litter Phosphorus-31 Nuclear Magnetic Resonance Spectroscopy: Extractants, Metals, and Phosphorus Relaxation Times. J. Environ. Qual. 31, 457-465.

Calegari, A., Costa, A., Rheinheimer, D.S., Tiecher, T., Casali, C.A., 2012. Conservation agriculture including cover crops and crop rotation can improve maize yield. In" The $3^{\text {rd }}$ International Conference on Conservation Agriculture in Southeast Asia". Conservation Agriculture and Sustainable Upland livelihoods. Innovations for, with and by farmers to adapt to local and global changes. Proceedings. Ha Noi, Vietnam. Printed by: Steps Media Co, Ltd. Hanoi Vietnam. CIRAD, NOMAFSI, University of Queensland. ISBNCIRAD: 978-2-87614-687-7. EAN CIRAD: 9782876146877. p. 253-255.

Calegari, A., Hargrove, W.L., Rheinheimer, D.S., Ralisch, R., Tessier, D., Tourdonnet, S., Guimarães, M.F., 2008. Impact of long-term no-tillage and cropping system management on soil organic carbon in an Oxisol: a model for sustainability. Agronomy Journal. 100, 1013-1019. 
Chavarría, D.N., Verdenelli, R.A., Serri, D.L., Restovich, S.B., Andriulo, A.E., Meriles, J.M., Vargas-Gil, S., 2016. Effect of cover crops on microbial community structure and related enzyme activities and macronutrient availability. Eur. J. Soil Biol. 76, 74-82.

Conte, E., Anghinoni, I., Rheinheimer, D.S., 2002. Fósforo da biomassa microbiana e atividade de fosfatasse ácida após aplicações de fosfato em solo no sistema plantio direto. R. Bras. Ci. Solo. 26(4), 925-930.

Corbeels, M., Marchão, R.L., Neto, M.S., Ferreira, E.G., Madari, B.E., Scopel, E., Brito, O.R., 2016. Evidence of limited carbon sequestration in soils under no- 374 tillage systems in the Cerrado of Brazil. Sci. Rep. 6. https://doi.org/10.1038/srep21450

Costa, A.C.S., 1996. Iron oxide mineralogy of soils derived from volcanic rocks in the Paraná River Basin, Brazil. Tese. (Soil Science PhD) - The Ohio State. 243p.

Dalla Costa, M.D., Lovato, P.E., 2004. Phosphorus fractions accumulated in clayey Latosol by the application of phosphate in the no-tillage system. Pes. Agrop. Bras. 39(6), 603-605.

Damon, P.M., Bowden, B., Rose, T., Rengel, Z., 2014. Crop residue contributions to phosphorus pools in agricultural soils: a review. Soil Biol. Biochem. 74, 127-137.

Darch T., Blackwell, M.S.A., Hawkins, J.M.B., Haygarth, P.M., Chadwick, D. 2014. Ametaanalysis of organic and inorganic phosphorus in organic fertilizers, soils, and water: implications for water quality. Crit Rev Environ Sci Technol 44: 2172-2202. https://doi.org/10.1080/10643389.2013.790752

Dick, W.A., Tabatabai, M.A., 1977. Determination of orthophosphate in aqueous solutions containing labile organic and inorganic phosphorus compounds. J. Environ. Qual. 6, 82-85.

Doolette, A.L., Smernik, R.J., Dougherty, W.J., 2011. A quantitative assessment of phosphorus forms in some Australian soils. Soil Research. 49, 152-165. http://dx.doi.org/doi:10.1071/sr10092

Elser, J.J., Elser, T.J., Carpenter, S.R., Brock, W.A., 2014. Regime shift in fertilizer commodities indicates more turbulence ahead for food security. PLoS One, 9 (5).

Fink, J.R., Inda, A.V., Tiecher, T., Barrón, V., 2016. Iron oxides and organic matter on soil phosphorus availability. Ciênc. Agrotec. 40(4), 369-379.

Haygartha, P.M., Harrison, A.F., Turner, L., 2018. On the history and future of soil organic phosphorus research: a critique across three generations. European Journal of Soil Science. 69, 86-94.

Hedley, M.J, Stewart, J.W.B., Chauhan, B.S., 1982. Changes in inorganic and organic soil phosphorus fractions induced by cultivation practices and by laboratory incubations. Soil Sci Soc Am J. 46(5), 970-976. 
Horst, W.J., Kamh, M., Jibrin, J.M., Chude, V.O., 2001. Agronomic measures for increasing P availability to crops. Plant Soil. 237, 211-223.

Hou, E., Tanga, S., Chenc, C., Kuang, Y., Lu, X., Heenan, M., Wen, D., 2018. Solubility of phosphorus in subtropical forest soils as influenced by low molecular organic acids and key soil properties. Geoderma. 313, 172-180.

Huang, L.M., Jia, X.X., Zhang, G.N., Shao, M.A., 2017. Soil organic phosphorus transformation during ecosystem development: A review. Plant Soil. 417, 17-42.

INSTITUTO AGRONÔMICO DO PARANÁ. IAPAR, 2003. Sugestão de adubação e calagem para culturas de interesse econômico no Estado do Paraná. Coordenação Edson Lima de Oliveira. Londrina (IAPAR. Circular, $\mathrm{n}^{\circ}$ 128). 30p.

INSTITUTO AGRONÔMICO DO PARANÁ. IAPAR. http://www.iapar.br/modules/conteudo/conteudo.php?conteudo=1865/ (accessed 15 December 2016).

Jian, X., Amelung, W., Cade-Menun, B.J., Bol, R., Willbold, S., Cao, Z., Klumpp, E., 2017. Soil organic phosphorus transformation during 2000 years of paddy-rice and non-paddy management in the Yangtze River Delta, China. Scientific Reports. 7(1), 1-12. http://dx.doi.org/10.1038/s41598-017-10071-0.

Kleber, M., Johnson, M.G., 2010. Advances in Understanding the Molecular Structure of Soil Organic Matter: Implications for Interactions in the Environment. Advances in Agronomy. $106,77-142$.

Klose, S., Tabatabai, M.A., 1999. Arylsulfatase activity of the microbial biomass in soil. Soil Sci. Soc. Am. J. 63, 569-574.

Loss, A., Basso, A., Oliveira, B.S., Koucher, L.P., Oliveira, R.A., Kurtz, C., Lovato, P.E., Curmi, P., Brunetto, G., Comin, J.J., 2015. Carbono orgânico total e agregação do solo em sistema de plantio direto agroecológico e convencional de cebola. Rev. Bras. Ciênc. Solo. 39(4), 1212-1224.

Mackay, J.E., MacDonald, L.M., Smernik, R.J., Cavagnaro, T.R., 2017. Organic amendments as phosphorus fertilizers: chemical analyses, biological processes and plant $\mathrm{P}$ uptake. Soil Biol. Biochem. 107, 50-59.

Marschner, P., Yang, C.H. Lieberei, R., Crowley, D.E., 2001. Soil and plant specific effects on bacterial community structure in the rhizosphere. Soil Biol Biochem. 33, 1437-1445.

Martinazzo, R., Rheinheimer, D.S., Gatiboni, L.C., Brunetto, G., Kaminski, J., 2007. Fósforo microbiano do solo sob sistema plantio direto em resposta à adição de fosfato solúvel. Rev. Bras. Ci. Solo. 31, 563-570. 
Mehlich, A., 1953. Determination of $\mathrm{P}, \mathrm{Ca}, \mathrm{Mg}, \mathrm{K}, \mathrm{Na}$ and $\mathrm{NH}_{4}$ by North Carolina Soil Testing Laboratoris. Raleigh: University of North Carolina.

Morel, C., Tiessen, H., Stewart, J.W.B., 1996. Correction for P sorption in the measurement of soil microbial biomass $\mathrm{P}$ by $\mathrm{CHCl}_{3}$ fumigation. Soil Biol. Biochem. 28(12), 1699-1706.

Murphy, J., Riley, J.P., 1962. A modified single solution method for the determination of phosphate in natural waters. Anal. Chimica Acta. 27, 31-36.

Olander, L.P., Vitousek, P.M., 2004. Biological and geochemical sinks for phosphorus in soil from a wet tropical forest. Ecosyst. 7, 404-419.

Olsen, S.R., Sommers, L.E., 1982. Phosphorus. In: Page, A.L., Ed., Methods of Soil Analysis Part 2 Chemical and Microbiological Properties, American Society of Agronomy, Soil Sci Soc Am J. , Madison. 403-430.

Parfitt, R.L., 1989. Phosphate reactions with natural allophane, ferrihydrite and goethite. Journal of Soil Science. 40, 359-369. http://dx.doi.org/doi.org/10.1111/j.13652389.1989.tb01280.x

Parfitt, R.J., Atkinson, R.J., Smart, R.C.T., 1975. The mechanism of phosphate fixation by iron oxides. Soil Sci. Soc. Amer. Proc. 39, 837-841.

Pavinato, P.S, Rodrigues, M., Soltangheisi, A., Sartor, L.R., Withers, P.J.A., 2017. Effects of cover crops and phosphorus sources on maize yield, phosphorus uptake, and phosphorus use efficiency. Agron. J.. 109 (3), 1039-1047.

Pavinato, P.S., Rosolem, C.A., 2008. Disponibilidade de nutrientes no solo: decomposição e liberação de compostos orgânicos de resíduos vegetais. Rev. Bras. Ciênc. Solo. 32(3), 911920.

Rheinheimer, D.S., Anghinoni, I., Flores, A.C., 2002. Organic and inorganic phosphorus as characterized by phosphorus-31 nuclear magnetic resonance in subtropical soils under management systems. Soil Sci Plant Anal. 33(13-14), 1853- 1871. http://dx.doi.org/10.1081/CSS-120004827.

Rheinheimer, D.S., Anghinoni, I., Conte, E., Kaminski, J., Gatiboni, L.C., 2003. Dessorção de fósforo avaliada por extrações sucessivas em amostras de solo provenientes dos sistemas plantio direto e convencional. Cienc. Rural. 33(6), 1053-1059.

Rheinheimer, D.S., Anghinoni, I., 2006. Accumulation of soil organic phosphorus by soil tillage and cropping systems under subtropical conditions. Communications in Soil Science and Plant Analysis. 34(15\&16), 2339-2354. http://dx.doi.org/10.1081/CSS120024068 . 
Rheinheimer, D.S., Martinazzo, R., Gatiboni, L.C., Kaminski, J., Silva L.S., 2008a. Amplitude no fósforo microbiano em um Argissolo em pastagem nativa submetida à roçada e à introdução de espécies forrageiras com fertilização fosfatada em diferentes épocas. Acta Sci. Agron. 30, 561-567.

Rheinheimer, D.S., Campos, B.C., Giacomini, S.J., Conceição, P.C., Bortoluzzi, E.C., $2008 b$. Comparação de métodos de determinação de carbono orgânico total no solo. Rev. Bras. Ciênc. Solo. 32, 435-440.

Richardson, A.E., Simpson, R.J., 2011. Soil Microorganisms mediating phosphorus availability. Plant Physiology. 156, 989-996.

Ridder-Duine, A.S., Kowalchuk, G.A., Gunnewiek, P.J.A.K.,, Smant, W., Van Een, J.A., Boer, W., 2005. Rhizosphere bacterial community composition in natural stands of Carexarenaria (sand sedge) is determined by bulk soil community composition. Soil Biol Biochem. 37, 349-357.

Rodrigues, M., Pavinato, P.S., Withers, P.J.A., Teles, A.P.B., Herrera, W.F.B., 2016. Legacy phosphorus and no tillage agriculture in tropical oxisols of the Brazilian savana. Sci. Total Environ. 542, 1050-1061.

SBCS/NEPAR, 2017. Manual of fertilization and liming for the Stateof Paraná. Editora Sociedade Brasileira de Ciência do Solo. Núcleo Estadual Paraná. $1^{a}$ Edição. 482p.

Solomon, D., Lehmann, J., Mamo, T., Fritzsche, F., Zech, W., 2002, Phosphorus forms and dynamics as influenced by land use changes in the sub-humid Ethiopian highlands. Geoderma. 105, 21-48.

Soltangheisi, A., Rodrigues, M., Coelho, M.J.A., Gasperinim, A.M., Sartor, L.R., Pavinato, P.S., 2018. Changes in soil phosphorus lability promoted by phosphate sources and cover crops. Soil Till. Res. 179, 20-28.

Tedesco, M.J., Gianello, C., Bissani, C., Bohnen, H., Volkweiss, S.J., 1995. Análise de solo, plantas e outros materiais. Porto Alegre, Universidade Federal do Rio Grande do Sul. 2.ed., 174p. (Boletim Técnico, 5).

Teles, A.P.B., Rodrigues, M., Herrera, W.F.B., Soltangheisi, A., Sartor, L.R., Withers, P.J.A., Pavinato, P.S., 2017. Do cover crops change the lability of phosphorus in a clayey subtropical soil under different phosphate fertilizers? Soil Use Manag. 33, 34-44.

Tiecher, T., Rheinheimer, D.S., Calegari, A., 2012a. Soil organic phosphorus forms under different soil management systems and winter crops, in a long term experiment. Soil Till. Res. 124, 57-67. 
Tiecher, T., Rheinheimer, D.S., Kaminski, J., Calegari, A., 2012b. Forms of inorganic phosphorus in soil under different long-term soil tillage systems and winter crops. Rev. Bras. Ci. Solo. 36, 271-282.

Tiecher, T., Calegari, A., Canerc, L., Rheinheimer, D.S., 2017. Soil fertility and nutrient budget after 23-years of different soil tillage systems and winter cover crops in a subtropical Oxisol. Geoderma. 308, 78-85.

Toledo, J.A., Kaminski, J., Santanna, M.A., Rheinheimer, D.S., 2012. Tampão Santa Maria (TSM) como alternativa ao tampão SMP para medição da acidez potencial de solos ácidos. Rev. Bras. Ci. Solo. 36(2), 427-435.

Tsujii, Y., Onoda, Y., Kitayama, K., 2017. Phosphorus and nitrogen resorption from different chemical fractions in senescing leaves of tropical tree species on Mount Kinabalu, Borneo. Oecologia. 185(2), 171-180.

Turner, B.L., 2008. Soil organic phosphorus in tropical forests: an assessment of the $\mathrm{NaOH}-$ EDTA extraction procedure for quantitative analysis by solution ${ }^{31} \mathrm{P}$ NMR spectroscopy. European Journal of Soil Science. 59, 453-466. http://dx.doi.org/10.1111/j.13652389.2007.00994.x

Turner, B.L., Cade-Menun, B.J., Condron, L.M., Newman, S., 2005. Extraction of soil organic phosphorus. Talanta. 66, 294-306.

Turner B.L., Mahieu, N., Condron, L.M., 2003. Phosphorus-31 nuclear magnetic resonance spectral assignments of phosphorus compounds in soil NaOH-EDTA extracts. Soil Sci Soc Am J. 67(2), 497-510

USEPA - United States Environmental Protection Agency. 1971. Methods of chemical analysis for water and wastes. Cincinnati: USEPA.

Vincent, A.G., Turnerb, B.L., Tanner, E.V.J., 2010. Soil organic phosphorus dynamics following perturbation of litter cycling in a tropical moist Forest. European J. Soil Sci. 61, 48-57.

Walker, T.W., Syers, J.K., 1976. The fate of phosphorus during pedogenesis. Geoderma. 15(1), 1-19. https://doi.org/10.1016/0016-7061(76)90066-5.

Wang, W., Shi, J., Xie, Q., Jiang, Y., Yu, N., Wang, E., 2017. Nutrient Exchange and Regulation in Arbuscular Mycorrhizal Symbiosis. Mol. Plant. 10, 1147-1158. http://dx.doi.org/10.1016/j.molp.2017.07.012.

Withers, P.J.A., Rodrigues, M., Soltangheisi, A., Carvalho, T.S., Guilherme, L.R.G., Benites, V.M., Gatiboni, L.C., Sousa, D.M.G., Nunes, R.S., Rosolem, C.A., Andreote, F.D., 
Oliveira Jr., A., Coutinho, E.L.M., Pavinato, P.S., 2018. Transitions to sustainable management of phosphorus in Brazilian agriculture. Sci Rep. 8, 25-37.

Wutke, E.B., Calegari, A., Wildner, L.D.O.P., 2014. Espécies de adubos verdes e plantas de cobertura e recomendações para uso. In: Lima Filho, O.F., Ambrosano, E.J., Rossi, F., Carlos, J.A.D. (Ed.). Adubação verde e plantas de cobertura no Brasil: fundamentos e prática. Brasília, DF: Embrapa, v.1, p.59-168.

Yevdokimov, I., Larionova, A., Blagodatskaya, E., 2016. Microbial immobilization of phosphorus in soils exposed to drying-rewetting and freeze-thawing cycles. Biol. Fertil. Soils. 52, 685-696.

Zamuner, E.C., Picone, L.I., Echeverria, H.E., 2008. Organic and inorganic phosphorus in Mollisol soil under different tillage practices. Soil Till. Res. 99, 131-138.

Zhang, L., Li, J., Rong, T., Gao, S., Wu, F., Xu, J., Li, M., Cao, M., Wang, J., Hu, E., Liu, E., Liu, Y., Lu, T., 2014. Large-scale screening maize germplasm for low phosphorus tolerance using multiple selection criteria. Euphytica. 197, 435-446. 


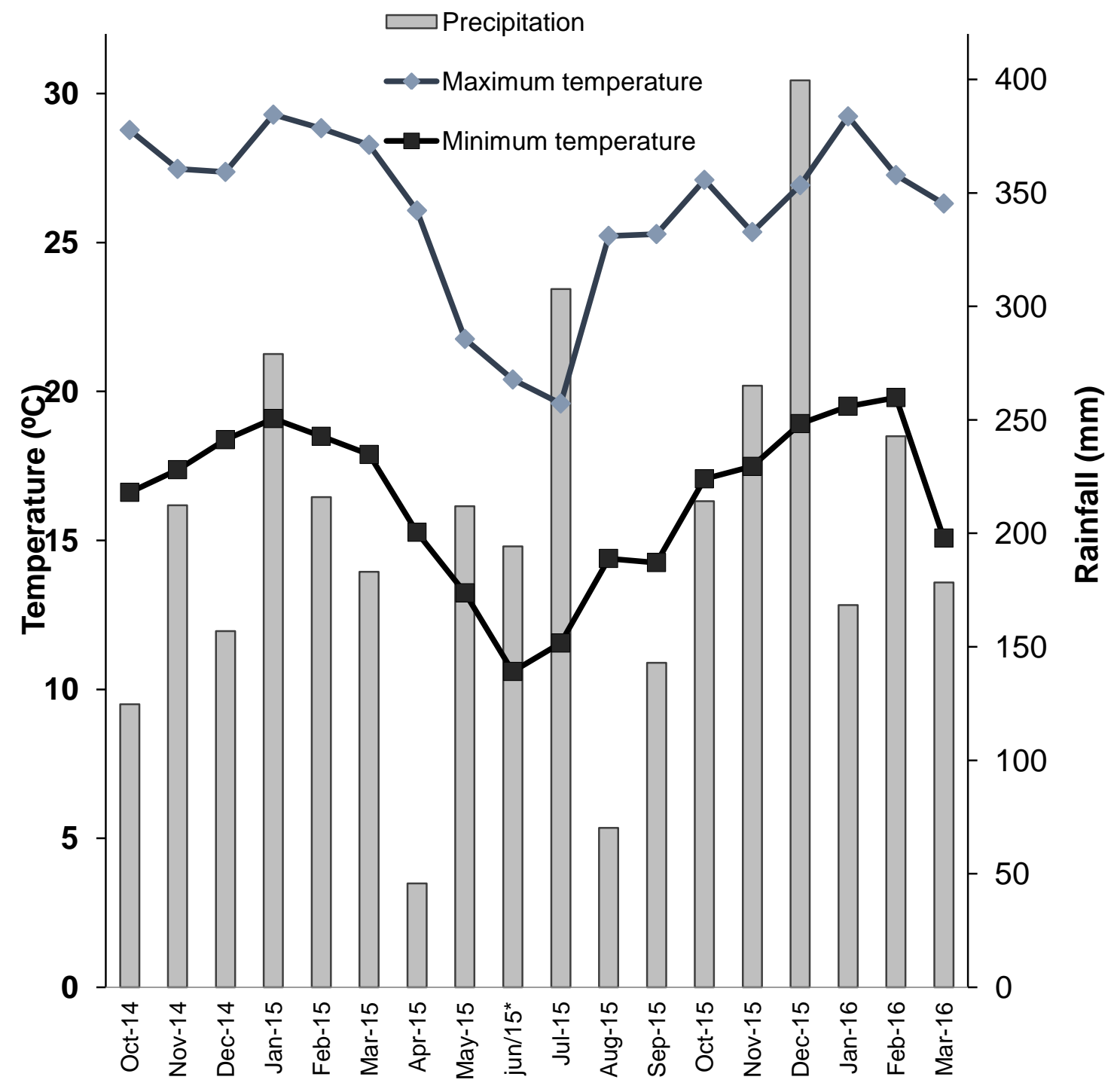

* Average of the last 30 years. Source: IAPAR Weather Station

Figure 1.Total rainfall $(\mathrm{mm})$ and averages of the maximum and minimum temperature $\left({ }^{\circ} \mathrm{C}\right)$ monthly from October 2015 to March 2016 in Pato Branco - PR - Brazil. 
Table 1. Winter cover species, summer species and rate of limestone application in the last 30 years in a very clayey Rhodic Hapludox located in Southwest of Paraná - Brazil.

\begin{tabular}{|c|c|c|c|}
\hline Year & Winter cover species & Summer species & Limestone $^{1}$ \\
\hline 1986 & All species & Corn & - \\
\hline 1987 & All species & Corn & - \\
\hline 1988 & All species & Corn & - \\
\hline 1989 & All species & Soybean & $1.0 \mathrm{Mg} \mathrm{ha}^{-1}$ \\
\hline 1990 & All species & Soybean & - \\
\hline 1991 & Black oat in all plots (except fallow) & Soybean & - \\
\hline 1992 & All species & Corn & $2.0 \mathrm{Mg} \mathrm{ha}^{-1}$ \\
\hline 1993 & Fallow in all plots & Soybean & - \\
\hline 1994 & All species & Corn & - \\
\hline 1995 & Black oat in all plots (except fallow) & Soybean & $3.0 \mathrm{Mg} \mathrm{ha}^{-1}$ \\
\hline 1996 & Black oat in all plots (except fallow) & Corn & - \\
\hline 1997 & Black oat + radish in all plots (except fallow) & Soybean & - \\
\hline 1998 & Black oat in all plots (except fallow) & Soybean & - \\
\hline 1999 & All species & Corn & $1.5 \mathrm{Mg} \mathrm{ha}^{-1}$ \\
\hline 2000 & All species & Soybean & - \\
\hline 2001 & All species & Soybean & $2.0 \mathrm{Mg} \mathrm{ha}^{-1}$ \\
\hline 2002 & Black oat + radish in all plots (except fallow) & Soybean & - \\
\hline 2003 & Black oat + radish in all plots (except fallow) & Corn & - \\
\hline 2004 & Black oat + radish in all plots (except fallow) & Soybean & - \\
\hline 2005 & All species & Soybean & - \\
\hline 2006 & Black oat in all plots (except fallow) & Fallow & $2.0 \mathrm{Mg} \mathrm{ha}^{-1}$ \\
\hline 2007 & All species & Soybean & \\
\hline 2008 & All species & Corn & - \\
\hline 2009 & Black oat + radish in all plots (except fallow) & Soybean & $2.0 \mathrm{Mg} \mathrm{ha}^{-1}$ \\
\hline 2010 & Black oat + vetch in all plots (except fallow) & Corn & - \\
\hline 2011 & All winter species & Corn & $2.0 \mathrm{Mg} \mathrm{ha}^{-1}$ \\
\hline 2012 & All winter species & Corn & - \\
\hline 2013 & All winter species & Soybean & - \\
\hline 2014 & All winter species & Corn & - \\
\hline 2015 & All winter species & Soybean & $2.0 \mathrm{Mg} \mathrm{ha}^{-1}$ \\
\hline 2016 & All winter species & - & - \\
\hline
\end{tabular}

${ }^{1}$ Superficial in no-tillage system and incorporated into the conventional tillage 
Table 2. Aboveground biomass yield of the plants grown during 30 years, under no-tillage system (NT) and conventional tillage (CT) under clayey Rhodic Hapludox in the experimental area located in the Southwest region of Paraná

\begin{tabular}{|c|c|c|c|c|c|c|c|c|}
\hline Winter species & winter & sidues & summe & esidues & cum & tive & & iean \\
\hline & NT & $\mathrm{CT}$ & NT & CT & NT & $\mathrm{CT}$ & NT & CT \\
\hline Vetch & 106.0 & 92.6 & 136.4 & 122.5 & 242.3 & 215.1 & 8.1 & 7.2 \\
\hline Wheat & 112.8 & 103.0 & 124.8 & 118.5 & 237.6 & 221.5 & 7.9 & 7.4 \\
\hline Ryegrass & 114.1 & 110.0 & 126.8 & 121.6 & 240.9 & 231.5 & 8.0 & 7.7 \\
\hline Rye & 124.6 & 103.8 & 133.1 & 123.9 & 257.6 & 227.7 & 8.6 & 7.6 \\
\hline Radish & 119.5 & 96.4 & 136.2 & 131.2 & 255.6 & 227.6 & 8.5 & 7.6 \\
\hline Hairy vetch + Black Oat & 140.2 & 113.7 & 128.1 & 127.4 & 268.3 & 241.1 & 8.9 & 8.0 \\
\hline Fallow $^{1}$ & 58.0 & 44.7 & 124.8 & 122.5 & 182.7 & 167.2 & 6.1 & 5.6 \\
\hline Average & 110.7 & 94.9 & 130.0 & 123.9 & 240.7 & 218.8 & 8.0 & 7.3 \\
\hline
\end{tabular}

${ }^{1}$ Considering the dry material of the weed overwinter in winter 
Table 3. Physical and chemical properties of a clayey Rhodic Hapludox in the $0-10 \mathrm{~cm}$ layer under no-tillage system (NT) and conventional tillage (CT) during 30 years.

\begin{tabular}{|c|c|c|c|c|}
\hline Parameter & Unit & $\mathrm{CT}$ & NT & Forest $^{1}$ \\
\hline $\mathrm{pH}$ & & $5.0 \mathrm{~b}$ & $5.2 \mathrm{a}$ & 4.5 \\
\hline $\mathrm{N}$ & \multirow{2}{*}{$\%$} & $0.2 \mathrm{~b}$ & $0.3 \mathrm{a}$ & 0.3 \\
\hline TOC & & $2.7 \mathrm{~b}$ & $3.5 \mathrm{a}$ & 3.6 \\
\hline K & \multirow{8}{*}{$\mathrm{cmol}_{\mathrm{c}} \mathrm{dm}^{-3}$} & $0.23 \mathrm{a}$ & $0.28 \mathrm{a}$ & 0.13 \\
\hline $\mathrm{Ca}$ & & $3.3 \mathrm{~b}$ & $5.0 \mathrm{a}$ & 1.9 \\
\hline $\mathrm{Mg}$ & & $1.5 \mathrm{~b}$ & $2.2 \mathrm{a}$ & 1.1 \\
\hline $\mathrm{Al}$ & & $0.5 \mathrm{~b}$ & $0.3 \mathrm{a}$ & 2.7 \\
\hline $\mathrm{H}+\mathrm{Al}$ & & $9.4 \mathrm{a}$ & $9.7 \mathrm{a}$ & 14.6 \\
\hline S & & $5.0 \mathrm{~b}$ & $7.5 \mathrm{a}$ & 3.1 \\
\hline $\mathrm{CTC}_{\text {effective }}$ & & $5.5 \mathrm{~b}$ & $7.8 \mathrm{a}$ & 5.8 \\
\hline $\mathrm{CTC}_{\mathrm{pH} 7}$ & & $14.4 \mathrm{~b}$ & $17.2 \mathrm{a}$ & 17.7 \\
\hline V & \multirow{2}{*}{$\%$} & $34.8 \mathrm{~b}$ & $45.3 \mathrm{a}$ & 17.6 \\
\hline $\mathrm{m}$ & & $9.0 \mathrm{~b}$ & $3.9 \mathrm{a}$ & 46.3 \\
\hline SSA & $\mathrm{m}^{2} \mathrm{~g}^{-1}$ & $44 \mathrm{a}$ & $42 \mathrm{a}$ & 44 \\
\hline
\end{tabular}

${ }^{\mathrm{T}}$ The native forest values were not used in the statistics. Equivalent capital letters do not differ statistically by the Tukey test at 5\% for management treatment. TOC: Total Organic Carbon; SSA: Specific Surface Area 
Table 4. Variance analysis for soil phosphorus forms in a clayey Rhodic Hapludox $(0-10 \mathrm{~cm})$ in a 30 years experiment with different soil management, winter cover crops and sampling time.

\begin{tabular}{|c|c|c|c|c|c|c|c|c|}
\hline Factors & $\mathrm{P}_{\mathrm{SMB}}$ & $\mathrm{P}_{\mathrm{R}}$ & $\mathrm{P}_{\mathrm{M}}$ & $\mathrm{Po}_{\mathrm{NaOH}}$ & $\mathrm{Pi}_{\mathrm{NaOH}}$ & $\mathrm{Po}_{\text {total }}$ & $\mathrm{Pi}_{\text {total }}$ & $\mathrm{P}_{\text {total }}$ \\
\hline Management $^{1}(\mathrm{M})$ & $17.20^{* * *}$ & $432.48^{* *}$ & $1032.27^{\text {** }}$ & $246.67^{* *}$ & $221.34^{* *}$ & $340.87^{* *}$ & $74.82^{*} *$ & na* $^{*}$ \\
\hline Sampling time ${ }^{2}(E)$ & $92.89^{* *}$ & $1.05^{\mathrm{ns}}$ & $2.48^{\mathrm{ns}}$ & $3.74^{*}$ & $3.74^{*}$ & $17.480^{* *}$ & $5.45^{* *}$ & $11.45^{*}$ \\
\hline Cover $\operatorname{crop}^{3}(\mathrm{C})$ & $2.72^{*}$ & $3.57^{* *}$ & $3.23^{* *}$ & $4.29^{* *}$ & $2.14^{\mathrm{ns}}$ & $8.97^{* *}$ & $7.71^{* *}$ & $9.49^{*}$ \\
\hline \multicolumn{9}{|l|}{ Interaction } \\
\hline M X E & $0.66^{\mathrm{ns}}$ & $9.01^{* *}$ & $2.67^{\mathrm{ns}}$ & $3.23^{*}$ & $0.37^{\mathrm{ns}}$ & $0.48^{\text {ns }}$ & $0.46^{\mathrm{ns}}$ & 0.034 \\
\hline $\mathrm{M} \times \mathrm{C}$ & $0.40^{\mathrm{ns}}$ & $2.89^{*}$ & $9.42^{* *}$ & $2.5772^{*}$ & $3.01^{*}$ & $1.67^{\mathrm{ns}}$ & $0.72^{\mathrm{ns}}$ & 0.66 \\
\hline $\mathrm{E} \times \mathrm{C}$ & $1.24^{\mathrm{ns}}$ & $7.02^{* *}$ & $3.34^{* *}$ & $7.3662^{* *}$ & $3.10^{* *}$ & $4.0590^{* *}$ & $2.72^{* *}$ & 1.91 \\
\hline$M \times E \times C$ & $0.79^{\text {ns }}$ & $6.39^{* *}$ & $4.54^{\mathrm{ns}}$ & $1.5516^{\mathrm{ns}}$ & $0.62^{\mathrm{ns}}$ & $2.70^{* *}$ & $1.38^{\mathrm{ns}}$ & 1.59 \\
\hline
\end{tabular}

${ }^{1}$ Management: conventional tillage (CT) no-tillage (NT). ${ }^{2}$ Sampling time: after corn harvest, winter species flowering and soybean flowering. ${ }^{3}$ Rotation: fallow, ryegrass, rye, vetch, radish, wheat and consortium hairy vetch and black oat.

${ }^{\text {na }}$ not available value. ${ }^{*}$ significant at the $5 \%$ probability level $(\mathrm{p}<0.05)$. ${ }^{* *}$ significant at the $1 \%$ probability level $(\mathrm{p}<0.01) .{ }^{\mathrm{ns}}$ not significant $(\mathrm{p}>0.05)$ 
Table 5. Phosphorus stored in soil microbial biomass in clayey Rhodic Hapludox $(0-10 \mathrm{~cm})$ in a 30 years experiment with different soil management, winter cover crops and sampling time.

\begin{tabular}{|c|c|c|c|c|c|c|c|c|c|}
\hline & Fallow & Ryegrass & Rye & Wheat & Vetch & Radish & Consortium $^{3}$ & Mean & Forest $^{4}$ \\
\hline & \multicolumn{9}{|c|}{ 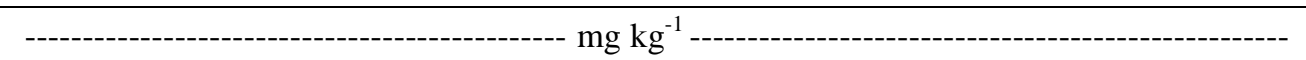 } \\
\hline \multicolumn{10}{|c|}{ Sampling Time ${ }^{1}$} \\
\hline Corn & 46 & 65 & 59 & 47 & 55 & 61 & 74 & 58 a & 38 \\
\hline Winter & 17 & 23 & 28 & 26 & 21 & 39 & 22 & $25 \mathrm{~b}$ & 38 \\
\hline Soybean & 20 & 30 & 23 & 20 & 39 & 18 & 27 & $25 \mathrm{~b}$ & 45 \\
\hline Mean & 28 B & $39 \mathrm{~A}$ & $37 \mathbf{A}$ & $31 \mathrm{~B}$ & $38 \mathrm{~A}$ & $39 \mathrm{~A}$ & $41 \mathrm{~A}$ & & 40 \\
\hline \multicolumn{10}{|c|}{ Soil Management $^{2}$} \\
\hline $\mathrm{CT}$ & 18 & 28 & 25 & 19 & 26 & 26 & 31 & $25 \mathrm{~b}$ & \\
\hline NT & 40 & 50 & 48 & 42 & 51 & 52 & 52 & $48 \mathrm{a}$ & \\
\hline
\end{tabular}

${ }^{1}$ After corn harvest; winter species flowering; soybean flowering. ${ }^{2} \mathrm{CT}=$ conventional tillage system; $\mathrm{NT}=\mathrm{no}-$ tillage system. ${ }^{3}$ Hairy vetch + Black oats. ${ }^{4}$ Values obtained in the forest soil were not included in the statistical analysis.

Means followed by the same lowercase letter comparing the sampling time or soil management system. Means followed by the same capital letter comparing the winter cover crops. 
Table 6. Phosphorus polls in clayey Rhodic Hapludox $(0-10 \mathrm{~cm})$ in a 30 years experiment with different soil management, winter cover crops and sampling time.

\begin{tabular}{|c|c|c|c|c|c|c|c|}
\hline & $\mathrm{P}_{\mathrm{M}}$ & $\mathrm{P}_{\mathrm{RTA}}$ & $\mathrm{Po}_{\mathrm{NaOH}}$ & $\mathrm{Pi}_{\mathrm{NaOH}}$ & $\mathrm{Po}_{\text {total }}$ & $\mathrm{Pi}_{\text {total }}$ & $\mathrm{P}_{\text {total }}{ }^{4}$ \\
\hline & \multicolumn{7}{|c|}{$\mathrm{mg} \mathrm{kg}^{-1}$} \\
\hline \multicolumn{8}{|l|}{ Soil Management $^{1}$} \\
\hline$\overline{\mathrm{CT}}$ & $5.0 \mathrm{~B}$ & $7.9 \mathrm{~B}$ & $277 \mathrm{~B}$ & $127 \mathrm{~B}$ & $371 \mathrm{~B}$ & $856 \mathrm{~B}$ & $1227 \mathrm{~B}$ \\
\hline NT & $13.9 \mathrm{~A}$ & $18.0 \mathrm{~A}$ & $364 \mathrm{~A}$ & $211 \mathrm{~A}$ & $463 \mathrm{~A}$ & 1047A & $1526 \mathrm{~A}$ \\
\hline \multicolumn{8}{|l|}{ Sampling Time $^{2}$} \\
\hline Corn & $9.8 \mathrm{a}$ & $12.8 \mathrm{a}$ & $319 \mathrm{ab}$ & $179 a$ & $437 \mathrm{a}$ & $964 a b$ & $1426 \mathrm{a}$ \\
\hline Winter & $9.4 \mathrm{a}$ & $12.6 \mathrm{a}$ & $330 a$ & $162 b$ & $409 b$ & $902 b$ & $1311 b$ \\
\hline Soybean & $9.0 \mathrm{a}$ & $13.4 \mathrm{a}$ & $312 b$ & $165 \mathrm{ab}$ & $404 b$ & $989 a$ & $1393 \mathrm{ab}$ \\
\hline \multicolumn{8}{|l|}{ Winter crops } \\
\hline Fallow & $10.8 a$ & $13.1 a$ & $304 a b$ & $172 a b$ & $397 c d$ & $970 a b c$ & $1367 b c$ \\
\hline Ryegrass & $9.7 a$ & $13.1 a$ & $329 a$ & $159 a b$ & $424 a b c$ & $858 c$ & $1282 c$ \\
\hline Rye & $11.8 a$ & $13.0 a$ & $328 a$ & $168 a b$ & $408 b c d$ & $893 c$ & $1301 b c$ \\
\hline Vetch & $8.1 a$ & $10.3 B$ & $333 a$ & $169 a b$ & $435 a b$ & $919 b c$ & $1354 b c$ \\
\hline HairyVetch + Black Oat & $9.7 a$ & $13.7 a$ & $325 a$ & $184 a$ & $411 b c d$ & $911 b c$ & $1321 b c$ \\
\hline Radish & $8.9 a$ & $14.0 a$ & $293 b$ & $151 b$ & $394 d$ & $1021 a b$ & $1416 b$ \\
\hline Wheat & $7.9 a$ & $13.1 a$ & $329 a$ & $177 a b$ & $448 a$ & $1091 a$ & $1595 a$ \\
\hline$\overline{\text { Forest }^{3}}$ & 4.6 & 5.7 & 389 & 147 & 436 & 832 & 1298 \\
\hline
\end{tabular}

${ }^{\mathrm{T}} \mathrm{CT}=$ conventional tillage system; NT= no-tillage system. ${ }^{2} \mathrm{After}$ corn harvest; winter species lowering; soybean flowering. ${ }^{3}$ Native forest values were not used in the statistics. ${ }^{1} \log (\mathrm{x})$ transformation for all data from the extractor column.

Equivalent capital letters, lowercase letters and lower case letters in italics do not differ statistically by the Tukey test at 5\% for management treatment, sampling time and winter crops, respectively. 
Table 7. Total and partial inorganic and organic phosphorus pools and phosphorus form analyzed by ${ }^{31} \mathrm{P}-\mathrm{NMR}$ in clayey Rhodic Hapludox $(0-10 \mathrm{~cm})$ in a 30 years experiment cultivated with common vetch winter cover crops (no-tillage and conventional tillage) and natural forest

\begin{tabular}{llll}
\hline Parameter & Forest & No-tillage & Conventional \\
\hline
\end{tabular}

Available P

Anion exchange resin $\left(\mathrm{mg} \mathrm{kg}^{-1}\right)$

$\begin{array}{ccc}5.0 & 15.4 & 7.6 \\ 33.4 & 55.1 & 23.4\end{array}$

Microbial biomass $\left(\mathrm{mg} \mathrm{kg}^{-1}\right)$

23.4

Total Digestion

Total P $\left(\mathrm{mg} \mathrm{kg}^{-1}\right)$

1,267

1,439

1,296

$\mathrm{Pi}\left(\mathrm{mg} \mathrm{kg}^{-1}\right)$

Po $\left(\mathrm{mg} \mathrm{kg}^{-1}\right)$

453

421

367

Po / Total P (\%)

35.7

29.3

28,3

Extracted by $0.5 \mathrm{~mol} \mathrm{~L}^{-1} \mathrm{NaOH}$

Total $\mathrm{P}\left(\mathrm{mg} \mathrm{kg}^{-1}\right)$

Pi $\left(\mathrm{mg} \mathrm{kg}^{-1}\right)$

Po $\left(\mathrm{mg} \mathrm{kg}^{-1}\right)$

Po / Total P (\%)

64.0

62.1

62.8

Extracted by $0.25 \mathrm{~mol} \mathrm{~L}^{-1} \mathrm{NaOH}+50 \mathrm{mmol} \mathrm{L}^{-1}$ EDTA $\left({ }^{31} \mathrm{P}\right.$-NMR Extract $)$

Total P $\left(\mathrm{mg} \mathrm{kg}^{-1}\right)$

$\mathrm{Pi}\left(\mathrm{mg} \mathrm{kg}^{-1}\right)$

Po $\left(\mathrm{mg} \mathrm{kg}^{-1}\right)$

Po / Total P (\%)

$P$ forms analyzed by ${ }^{31} P-N M R$

Orthophosphate (\%)

51.0

62.0

56.8

Monoester (\%)

Pyrophosphate (\%)

2.6

Diester (\%)

6.6

3.1

5.1

Adenosine diphosphate (\%)

0.6

0.9

0.0

Monoester/Diester ratio

5.9

Po / Total P (\%)

46.4

33.7

40.9 